\title{
CITIZEN JOURNALISM AND COMMUNITY BUILDING: PREDICTIVE MEASURES OF SOCIAL CAPITAL GENERATION
}

\author{
A Thesis \\ presented to \\ the Faculty of the Graduate School \\ at the University of Missouri-Columbia \\ In Partial Fulfillment \\ of the Requirements for the Degree \\ Master of Arts \\ by \\ JEREMY LITTAU
}

Dr. Clyde H. Bentley, Thesis Committee Chair

MAY 2007 
C Copyright by Jeremy Littau 2007

All Rights Reserved 
The undersigned, appointed by the dean of the Graduate School, have examined the [thesis or dissertation] entitled

\section{CITIZEN JOURNALISM AND COMMUNITY BUILDING: PREDICTIVE MEASURES OF SOCIAL CAPITAL GENERATION}

presented by Jeremy Littau,

a candidate for the degree of master of arts,

and hereby certify that, in their opinion, it is worthy of acceptance.

\begin{tabular}{c}
\hline Professor Clyde Bentley \\
\hline Professor Esther Thorson \\
\hline Professor Doug Raber \\
\\
Professor Tom Warhover \\
\hline
\end{tabular}




\section{DEDICATION}

This work is dedicated to my wife Amy White. It is difficult to imagine life without her, let alone what the following work would amount to without her commitment and support.

This work also is submitted in the memory of my father-in-law Larry Wallace White, who died on September 28, 2006 after a long struggle with cancer. Larry taught us all that life is indeed precious and worth fighting for, and that in the toughest of times it is the strength of character that shines through. We miss him greatly. 


\section{ACKNOWLEDGEMENTS}

Of all of the things I have learned in my time here at the University of Missouri, perhaps the most important thing I have learned is that good scholarship generally rises from the connections and collaboration with those around you. If nothing else, this work attempts to embody that principle in that it is not merely the product of collaboration with my committee members but also the countless professors, classes and hours of discussion that form the backdrop for any research endeavor.

Special thanks go to my committee members: Dr. Clyde Bentley (chair), Dr. Esther Thorson, Dr. Doug Raber, and Missourian editor Tom Warhover.

Dr. Bentley is responsible for making me view a world outside desk journalism, one with limitless opportunities for exploration and study. His influence in helping me become a better scholar and thinker are immeasurable, and his personal guidance through some tough waters the past year cannot be repaid.

Dr. Thorson was patient and extremely helpful in going over the methods portion of this work as well as helping me see connections to theory. My best experiences here at MU have come when I got to do hands-on work that was both practical in terms of experience and also offered teaching moments. Dr. Thorson graciously granted me both even though she has so much of her own work to do, and I am grateful for that.

Dr. Raber spurred my thinking in different ways about theoretical implications of citizen journalism and its impact on communities. He challenged me to explore the theoretical structure of a broad proposal and flex my thinking on the issues around it. 
Columbia Missourian editor Tom Warhover represents a unique and important part of my committee, the rare journalist who deals in both the practical and theoretical. In some ways, this work is written for people such as him and it is with that in mind that I continue my studies in an effort to find more ways to make turn theory into practice.

I would be remiss in not giving special thanks to fellow graduate students Brian Hamman and Fred Vultee, both of whom offered much-needed help in understanding the monster that is SPSS. I will never run a factor or regression analysis without thinking of them and the guidance they gave.

Finally, it is important to me to thank my family for all of their support the past two years. They supported my crazy little grad school dream, saw me through a marriage and offered an outstretched hand at the passing of Amy's father. With that much support in such a short amount of time, it is difficult to imagine a person luckier than me. 
TABLE OF CONTENTS

ACKNOWLEDGEMENTS ............................................................................

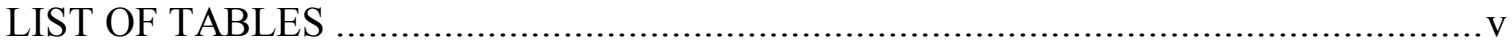

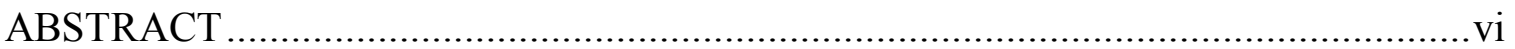

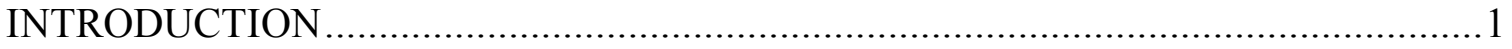

REVIEW OF THE LITERATURE .................................................................... 7

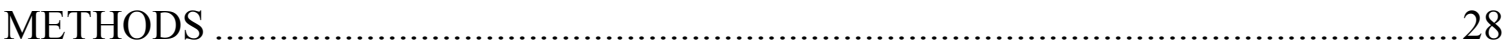

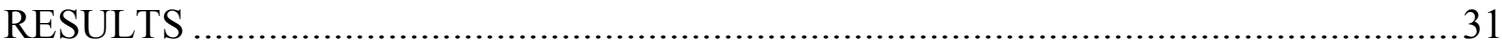

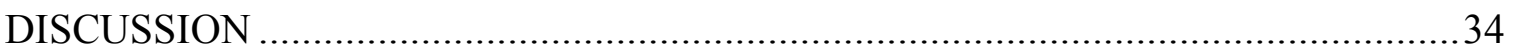

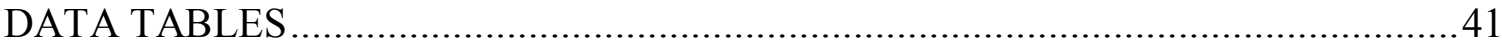

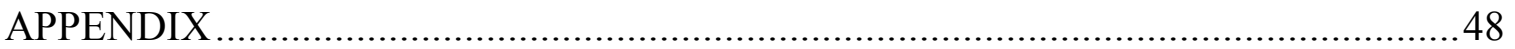

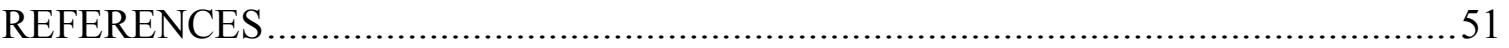




\section{LIST OF TABLES}

Table

Page

1. Rotated Component Matrix for Community Involvement …........................... 41

2. Reliability Test for Civic Involvement Scales .............................................41

3. Rotated Component Matrix for Gratifications ..................................................42

4. Reliability Test for Gratifications Scales.................................................... 42

5. Correlation of IV (Gratifications) to DV (Community Involvement).....................43

6. Correlation of Independent Variable Factors.................................................... 43

7. Correlation of Dependent Variable Factors ................................................... 44

8. Means for Writers vs. Readers for Gratifications and Community

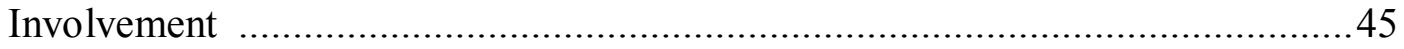

9. Writers vs. Readers for Gratifications and Community Involvement (independent samples t test) ............................................45

10. Final Model Predicting Community Activity Participation ................................46

11. Final Model Predicting Working in Community ........................................46

12. Final Model Predicting Activism in Community.............................................47 


\title{
CITIZEN JOURNALISM AND COMMUNITY BUILDING: \\ PREDICTIVE MEASURES OF SOCIAL CAPITAL GENERATION
}

\author{
Jeremy Littau
}

Dr. Clyde H. Bentley, Thesis Committee Chair

\begin{abstract}
A survey $(\mathrm{N}=102)$ of citizen journalism readers explored the relations between motivations for reading (content and process gratifications), personal attitudes (interpersonal trust and life contentment), and three measures of community participation (civic engagement, interpersonal trust, life contentment. The gratifications and personal attitudes were highly predictive of community participation. Only a few differences were observed between citizens who contributed journalism and those who only read it.
\end{abstract}




\section{INTRODUCTION}

It is difficult to guess when any burgeoning form of communication becomes a cultural phenomenon. For the ever-growing phenomenon that is "citizen journalism", though, that date could well be July 7, 2005. On that tragic day, four coordinated attacks were set in motion aboard London's train system during the morning hour, with three bombs going off "nearly simultaneously" at 8:50 a.m. and a fourth detonating nearly an hour later (Frankel, 2005).

Amidst the chaos and carnage emerged a new public voice, one coming from

citizens armed with camera phones rather than traditional photojournalists carrying telephoto lenses and tripods (Dunleavy, 2005). The result was a type of spot news coverage previously unseen, a place where the immediacy of news came together with powerful technology to help create what one writer hailed as "history's new first draft" (Braiker, 2005).

No longer were journalists the only ones telling the stories. Web sites such as MSNBC have helped to explode the role of the citizen-as-journalist by creating a space for text and photos for events such as Hurricane Katrina, the London bombings, and Hurricane Wilma (MSNBC, 2005). Citizen journalism, only two years ago still in the experimental stages here in the United States (Bentley et al., 2005), had gone from an interesting journalism trend to a full-blown phenomenon (Braiker, 2005).

What is interesting about this turn is that it could possibly cause the media to retool established work in media and community involvement. Numerous studies have 
found that news media use, particularly use of newspapers, has correlated highly with all sorts of factors related to community involvement (Cannon, 2005). Study after study has tried to find relationships which look at ways media use affects participation, but citizen journalism is by nature participation itself (Bentley et al., 2005).

The purpose of this study is to examine the relationship citizen journalism has to the production of social capital. Specifically, it will attempt to look at the relationship between social capital production and a person's usage of a citizen journalism medium. If we know from past research that newspaper readership tends to lead to greater civic involvement, then what does that tell us about citizen journalism? Does using this medium help to predict the production of social capital in ways similar to traditional media and online media, or does interactive and participatory nature of the medium itself set it apart from those other forms?

The questions this study attempts to answer go to the heart of journalism's role in democracy. From the notion that journalism is a pillar of democracy (Hutchins, 1947) to theories that journalism helps facilitate a marketplace of ideas (Flink, 1997), scholars have for years been attempting to come up with a "better journalism", one which builds communities and strengthens democracies.

This study is important for many reasons, not the least of which is that newspapers appear to be losing their hold on their audiences (AFP.com, 2005). Revenues are shrinking for the traditional print product due to declines in circulation related to drops in advertising (Krueger \& Swatman, 2004) and competition from other forms of emerging media (Walker, 2005). 
Taking all of these problems into account, the stark numbers reveal an even bleaker trend: double digit declines in circulation at several major newspapers according to a recent $\mathrm{ABC}$ audit, an overall drop of $2.6 \%$ in weekday circulation among nearly 800 dailies and a drop of $3.1 \%$ in Sunday circulation. Even smaller community newspapers were not immune to the declines (Maloney, 2005).

Another major threat to revenues is classified revenue losses to Craigslist, a popular Web site founded by Craig Newmark. Craigslist has a national reach but also regionalizes the site's content by community. On the site are discussion boards and community groups, but the big problem for a newspaper is the free classified ad section. The classifieds section is enormously popular, especially among younger users, and has the potential to cut deeply into classified revenues. Despite the threat that Craigslist poses, it also represents the shift in thinking that drives citizen journalism. By 2005, only five years after it launched, it was receiving as many page views a day as Amazon.com despite having only 14 people on staff. It is free to use and banner-free in terms of advertising, with paid classifieds for businesses in a few major cities serving as the company's revenue source. Its goals are largely philanthropic as it attempts to build and engage its user community in ways that promote growth and connections among people (Galiel, 2004).

Newmark and his company have become darlings among citizen journalism advocates (Galiel, 2004; Leeson, 2005), as he was a panelist at both the Association for Education in Journalism and Mass Communication in San Antonio in August 2005 and the WeMedia conference in New York in October 2005. When estimates that the site 
took $\$ 50$ million to $\$ 60$ million away from local newspapers in classified advertising were detailed by local Bay Area media, Craigslist CEO Jim Buckmaster had strong words for newspaper publishers who bemoaned the data. Ironically, he noted that the site is intended to be nothing but a service to its readers, which is how many view the mission of newspapers.

"It's possibly a cynical cop-out by the moneyed interests at newspapers to point fingers at Craigslist. Newspapers are cutting their investment in reporting. They're running more Associated Press wire stories and increasing the percentage of the product they devote to advertising and alienating readers. But it's much easier to point the finger at a site like Craigslist." (Fost, 2005)

For those attempting to salvage newspapers from this decline and address several of the issues raised by those such as Newmark, the response tends to take one of two courses: remake the newspaper in a way that will appeal to new readers, or reinvent the newspaper altogether (Bakker, 2002; Raeymaeckers, 2004).

Citizen journalism is an attempt at the latter, and it does it in a unique way. It is an attempt to give some power back to the readers, and in doing so it gives them a larger role in the community discussion by turning some readers into writers and the professional journalist into a "shepherd" in the process (Glaser, 2004). It takes some of the goals of public journalism and repackages them in a format that is more than just reader-driven. It is reader-produced as well.

Although the journalist-as-gatekeeper role remains because they still make decisions about what to promote on the front page, for example, the scope of this activity is much more limited because they are not assigning stories or topics. In short, journalists are not guarding the gates of information, they are throwing the doors wide 
open and inviting everybody in and then deciding in small ways what to play up in terms of editorial presentation (Dube, 2005).

Those who study citizen journalism have been driven by the notion that this burgeoning new medium offers the average person a greater chance to contribute and participate in their community. The sense is that citizens have had their voice shut out of the civic conversation by the gatekeeping role the press plays (Deuze, 2003) but that citizen-driven media takes away the emphasis on gatekeeping and instead emphasizes the citizen's participation in civic discussion.

This study will examine the research question by looking closely at those who subscribe to one citizen journalism publication. MyMissourian has been online since October 1, 2004. It consisted of only an online Web edition in its first year, but on October 1, 2005 it launched a print edition that culls material from the online edition for print in a standard broadsheet format. This print edition is essentially the parent Missourian's TMC (Total Market Coverage) edition (known as a "shopper" in some industry circles). It had been filled with previously published stories from the week before, and so the opportunity to publish fresh material in the form of a "best of" MyMissourian edition was seen as a chance to try growing both the Missourian and MyMissourian products without added cost. In its first year there were 537 registered users, but in the two months since the launch of the print product registrations reached nearly 750 registered users.

MyMissourian was chosen for study for several reasons. First, it is a seasoned citizen journalism product that was built from the ground up. Second, it was built for the 
purpose of research and does not have revenue generation as its primary goal, and thus using results from this survey for the purposes of further research could prove less difficult in the future. Third, this study is intended to be part of a research stream that has been created around MyMissourian. Those working to build up the MyMissourian are interested in both the reach and effectiveness of the site in reaching the community, and this research is intended to be another piece in that puzzle. By combining those efforts, we are hoping to come up with a broad description of citizen journalism that is driven by both theory and research.

In the interest of disclosure, it should be noted that the author has been heavily involved with MyMissourian since its inception. While it could be noted that there might be conflicts of interest in seeing the project succeed, the author's interest has always been in testing it as a vehicle for research when it comes to community building. All members of the committee approving this work were aware of that at the proposal defense. 


\section{REVIEW OF THE LITERATURE}

\section{Citizen journalism defined}

"Citizen journalism" is a popular label used to describe a form of media that involves moderated reader participation. It generally starts off as a Web-based approach, but one of the long-term strategies is to develop a "best of" print edition that ultimately will serve as the medium's revenue source. The Northwest Voice, which is the citizen journalism arm of The Bakersfield Californian, used material from the Web edition to revive its shopper edition (Terdiman, 2004). The paper's own institutional research showed that readership of its regular shopper edition was low, and this was not pleasing to advertisers. Mary Lou Fulton, drawing upon an idea pioneered in South Korea, guided the start of a community Web site that was run solely on story and photo submissions from the community (Bentley et al., 2005). As content increased, the material eventually replaced the stale material that often stocked the shopper editions. Readership increased for several reasons. There was a "refrigerator door" effect, meaning that citizens were reading the print version of The Northwest Voice more closely because it included news important to them or about them that was akin to putting a child's hand-drawn picture on the refrigerator as a source of pride and enjoyment (Glaser, 2004).

But beyond the popular definition and the benefits in rebuilding sagging publications, what is citizen journalism? In point of fact, citizen journalism reverses the sender-receiver process of traditional journalism. Whereas newspaper, television and Web media use the journalist as a "gatekeeper" in the process of selecting and presenting 
news, in the citizen journalism format the journalist is a "shepherd" in the process (Glaser, 2004). What this means is that the journalist's role is to seek out community voices and encourage submissions; their only editing role is in making sure that copy is readable and does not open the publication to legal problems such as libel or defamation, and then they make selections as to what goes on the main pages of the Web site (Bentley et al., 2005). Consider what Fulton told Online Journalism Review:

"We are the traditional journalism model turned upside down. Instead of being the gatekeeper, telling people that what's important to them 'isn't news,' we're just opening up the gates and letting people come on in. We are a better community newspaper for having thousands of readers who serve as the eyes and ears for the Voice, rather than having everything filtered through the views of a small group of reporters and editors." (Glaser, 2004)

In its beginnings it was referred to as "participatory journalism" or "open source journalism," (Bentley et al., 2005) but it also has been referred to as "grassroots journalism" and "user-generated content" (Gillmor, 2004; Schweiger \& Quiring, 2005).

For the purposes of this paper, we will use the term "citizen journalism" due to its overwhelming acceptance in industry circles and trade publications, but it is more important here to present a clear conceptual definition if for no other reason than the term "citizen" has proven to be problematic for some when assessing this new type of medium. Little scholarly research has been published on this burgeoning medium due to the fact that it is relatively new, and thus one of the goals of this work will be a clearer definition of what citizen journalism is in terms of both past theoretical and conceptual work. 
Conceptually, it is preferable to examine citizen journalism as a journalistmoderated community blog. This ties together several characteristics seen in the literature and allows for synthesis in terms of what has been researched, and it makes use of strengths offered by several different online formats, including moderated forums and blogs.

The first item to look at is the term of moderation, which conceptually is defined by the gatekeeper role performed by editors. Classic agenda-setting theory notes that the journalist uses gatekeeping as editorial selection to determine the public discussion (McCombs \& Shaw, 1974). It is worth noting that while greater public discussion is a goal of those who promote citizen journalism (Ananny \& Strohecker, 2002), the direction or topics for discussion is often not the concern of the editor involved as we shall discuss later on.

The second notion that is part of our citizen journalism definition is that of the blog. There are many types of blogs, and what citizen journalism attempts to do is use the community blog format and combine that with gatekeeping roles found on news Web sites. Most researchers by now accept blogs as simply being Web pages with several entries that are listed in reverse chronological order (Rodzvilla, 2002). This definition is extraordinarily flexible because it makes distinctions between the different types of blogs that exist. The writing can be done by one person or it can be a community blog, which is constructed by several members who are pre-approved to be able to post to the site. It can be personal or expressive, and it can be written in any manner from everyday prose to formal essay style. It also can be layered in that entries can either all go on the main 
page, or they can be sorted according to preset conditions such as how recent they are or by category (Bar-Ilan, 2004). One misconception about blogs is that they usually are political. The opposite is actually true; they tend to be more about daily events, and political writing tends to be woven in with non-political elements such as daily life events (Rodzvilla, 2002).

Another point worth noting is that citizen journalism is going to force a reshaping of current theories about online journalism. Deuze (2003) theorizes four types of online journalism that are deployed along an axis: mainstream news sites, index and category sites, meta and comment sites, and sites for both sharing and discussion. The horizontal axis, which ranges from left to right, goes from an emphasis on editorial content to an emphasis on public interaction. The vertical axis, from top to bottom, goes from an emphasis on moderated participatory communication to unmoderated participatory communication.

Mainstream news sites offer originated (original copy produced for the Web medium) or aggregated (taken from the parent medium and replicated for the Web, sometimes called "shovelware") content with very little participation from users; most online newspaper sites, Deuze notes, fall into this category. Index and category sites do not produce original content, but rather link to it; examples would include portal sites such as Yahoo or the Drudge report, but some blogs also fit into this category. Meta and comment sites are sites are sites about journalism itself, written by journalists and often containing comment about how the news is produced rather than comments about the news itself. Share and discussion sites offer places for users to connect with one another 
and exchange ideas in an open forum. Group (or community) blogs or discussion sites such as Slashdot are good examples of this type of online journalism (Deuze, 2003). The rise of the "Web 2.0" type of news sites, though, seems to reveal a trend toward combining some of these elements, which is why Deuze's model works so well. Since it technically consists of a grid involving different continuums, a given site can be charted along this axis depending on its level of interactivity and control.

Where does citizen journalism fit in this grid? It mostly exhibits characteristics of share and discussion sites for the most part, because the emphasis is on participation and exchange of ideas. But unlike sites such as Slashdot, those building citizen journalism Web sites often are seeking out people in the community to write. It is not a "coming together" of like-minded people or on a topic of shred interest that occurs without an attempt at seeking out those like-minded people, unlike the Slashdot model. In other words, it's often hard work trying to build this type of online community, because it requires bridging together groups and people who are separated in the real world (Norris, 2002). Thus it would seem that citizen journalism is more of a hybrid between a mainstream news site and a share and discussion site.

Citizen journalism is partly built on the personal nature of blog writing. It can be written in first person or third person. If a person decides to weave opinion with fact, that is considered acceptable; the basic tenet is that community members are not trained to think or write in the artificial standard of media objectivity, and thus they often are not forced to adopt that standard (Bentley et al., 2005). In addition, citizen journalism is more like a community blog in the sense that there are multiple authors, but unlike a 
typical community blog there are no limits placed on who is allowed to submit to the site (Glaser, 2004). One of the reasons this format works is the explosion in ownership of an array of citizen journalism tools such as digital cameras, camera mobile phones, computers and iPods. With these tools affordable and broadband penetrating more homes in America than ever, the time is right for citizen journalism to make inroads into communities once dominated by a single newspaper or television station (Gillmor, 2004).

The notion that citizen journalism is moderated is what separates citizen journalism from a typical community blog, and in fact is what elevates the posting format into a news format. The editor running the site often determines what is placed on the front page, and thus the gatekeeper role still happens to a limited a degree (Glaser, 2004). Citizen journalism sites often are designed like a news site, not a blog, and thus there are layered pages in which there is a main front page and several topic categories. Still, the gatekeeper role is greatly diminished from what it would be at a typical news site, because the editor would determine both what makes the front page and what stories make it onto the site. Unless the stories violate standards for submission, citizen journalism sites tend to publish anything submitted. These standards depend on the site, but they can be less restrictive than typical news sites (Bentley et al., 2005; Bentley, 2004).

So what are the standards considered for gatekeeping? Design tends to be a big concern; photos that would be attention-grabbing tend to make the front pages, as do more dramatic stories (Glaser, 2004). Also, many sites have incorporated the use of statistical software in their design. The result is that modules within the site software can 
move the most popular stories to the front page, giving the site's readers more of a choice in what goes on the front. In essence, though, the main gatekeeping function typically involves choices that determine where a story is played on the site (front page compared to a layered subpage) as well as what stories are pulled for the print edition, if a site has one.

\section{Social Capital}

Most scholars have linked the research between local knowledge and voting in local elections using the theoretical concept known as social capital, and that is the theoretical framework by which we will look at this research question. Social capital is defined as "the features of social organization such as networks, norms, and social trust that facilitate coordination and cooperation for mutual benefit" (Putnam, 1995). The social capital model thus says that by becoming involved with local groups or organizations helps build trust among those in the community (Putnam, 1993). Civic engagement is often the way in which this is measured. The idea is not merely that people are involved with one another's lives, but also that people are involved to the extent that they will act through those social networks for the purpose of creating a better quality of civic life.

Quality of civic life is measured by three indicators: individuals' engagement in community activities, interpersonal trust, and life satisfaction (Putnam, 1995; Uslaner, 2004). Trust in others and community engagement form what some researchers have called a "virtuous circle of social capital" in that greater trust in individuals in one's community lead to greater civic engagement, which in turn increases social trust (Shah, 
Kwak, \& Hobert, 2001). Life satisfaction, defined by Shah as "personal contentment" (Shah et al., 2001), increases the view of legitimacy of government and leads to a more efficient and beneficial government (Inglehart, 1997). The purpose of social capital creation is that it can, in a sense, be "spent" or "invested" back in the community. When somebody does work in the community such as volunteering, they improve the lives of others, and this in turn leads to greater life satisfaction and interpersonal trust of one's neighbors. Thus the idea of the virtuous circle, as the social capital cycle is self-feeding.

This notion has been tested across all media. Societies which see high levels of voluntary activity and social activity beyond the network of their home lives often see higher rates of literacy, income, civic participation, and life satisfaction (Hall, 1999). People in such societies tend to experience efficient government and higher incomes than societies with lower amounts of civic engagement (Knack \& Keefer, 1997; Whiteley, 2000).

Civic engagement has been measured many ways, but in general it looks for activity related to political or social involvement. Political involvement originally was measured in terms of political knowledge, but soon it came to be seen as a function with involvement with political organizations and media use (Almond \& Verba, 1989; Pateman, 1970). Social involvement has typically been studied in terms of work in nonprofit groups, church attendance, volunteerism, schools, and other civic organizations aimed at improving community life (Uslaner, 2004).

Social capital research can be linked in part to Habermas' notion of the public sphere. Habermas notes that public spheres can be defined as "the domain of our social 
life in which such a thing as public opinion can be formed" (Habermas, 1989). Citizens act as a public when they are able to assemble freely and without coercion, but sometimes media are required to organize the citizen debate and help the community come together. This has been defined as the "marketplace of ideas" first articulated by John Milton and later incorporated into legal frameworks in a Supreme Court decision authored by Oliver Wendell Holmes. Milton wrote that truth and error should be allowed to "grapple in the marketplace of ideas," and it was his belief that this process will allow the public to refine the debate and realize the truth (Milton, 1986).

Many studies, both new and old, have examined media use vis-à-vis civic engagement. There has been a consistent link established between newspaper readership and voting in local elections, for example (Beaudoin \& Thorson, 2004). The level of knowledge concerning issues of local interest has strongly correlated with newspaper use (Becker \& Dunwoody, 1982).

Also related to social capital is the notion of civic duty. Several studies have found that one of the underlying reasons behind newspaper readership at a local level has been a sense of civic duty to be informed, and thus that civic duty may be what is driving people to not only be more active among their fellow citizens but also to follow through with that and translate it into a trip to the voting booth (Pointdexter \& McCombs, 2001). This has profound implications for studies in online local news readership, because the online format has been seen thus far as a place where like-minded people can come together much more easily for the purpose of civic discussion (Norris, 2002). 
The focus of much social capital in media research, at least in the past 15 years, has been the public journalism movement, and this heavily relates to the study of online local media use. Public journalism seeks to directly engage the public by enlarging the civic discussion, and it takes a more active role in making than happen than does traditional journalism (Merrill, Gade, \& Blevens, 2001).

Public journalism stresses the notion of building community by educating the people in the community. Its roots are traced to the 1988 U.S. presidential campaign and the frustration that came out of realizing that the media tend to cover elections as a horse race, with the only true loser being the public debate itself (Rosen \& Merritt, 1994). Thus public journalism attempts to reengage the public by covering the issues and ideas that are most important in a community, putting aside the discussion of the day-to-day poll numbers that often drive news coverage of election campaigns.

Public journalists seeks to create discussion in the community; often times they are trying to do so in a place where there has been no public discussion. This takes many forms, from organizing local "town hall" meetings sponsored by the publication to employing a community organizer at the newspaper itself to help facilitate community discussion with newspaper coverage (Merrill et al., 2001).

In terms of online communities and social capital research, little has been done in terms of trying to establish whether the link that exists between newspaper readership and local voting patterns also applies to online local news readership. There is, though, plenty of developed theory about online local news as it relates to social capital theory. 
One interesting application of the work done by Putnam is the notion that online communities play both a bridging and bonding role. Putnam theorizes that there are two types of social capital that interplay in online communities. Bridging social capital is the notion of using social networks to bring together people of different sorts, whereas bonding social capital tends to bring together people of the same sort for the purposes of reinforcing shared values in a community (Putnam, 2001).

Bridging and bonding both are seen as a strength of online communities, because these groups have the ability to bring together people of like backgrounds as well as connect people with groups of different viewpoints with whom they might not normally interact (Norris, 2002). This actually corresponds with findings from some citizen journalists, which found that some groups traditionally ignored by the media and thus bordering on disengagement were able to find a place to be heard through citizen journalism (Bentley et al., 2005).

\section{Uses and gratifications theory}

Much research up until the 1970s focused on mass media's effects on the user, and it was believed at one point that mass media study was far too narrow (Katz, 1959). After penning a piece that challenged the scholarly community to come up with new ways of examining mass media, Blumler and Katz pioneered uses and gratifications (henceforth referred to as "U\&G") as an approach that looked at media in terms of how it met the social or psychological needs of the person using that medium (Blumler \& Katz, 1974). To examine mass media from the point of view of the audience was, for its time, 
a revolutionary way to look at mass media (Klapper, 1963) even if we consider that perspective today to be a given.

The Blumler \& Katz study noted there are five crucial assumptions to this theoretical approach that guide research in this area. The first assumption is that the audience is active, that they are an active part of the communication process. The second assumption is that users are goal-oriented in their media use, and that the goal is to fill their needs through media consumption. Third, mass media compete with other sources of need satisfaction, and in fact mass media serve only a small part of the needs to be satisfied for a given individual. Fourth, many goals about media use can be taken from data supplied by the audience members themselves, which means that surveys and selfreports are a common tool of $U \& G$ research. Lastly, the researchers asserted that value judgments about the cultural significance of mass communication should be put on hold until further study could be given to audience operations (Blumler \& Katz, 1974).

Blumler \& Katz also noted that individuals can use the same media to gratify different needs, and also that mass media could be used in different ways by different individuals (Blumler \& Katz, 1974). But what are these needs that make up the theory? One study suggested four ways in which people and media interact. First was diversion, defined as an escape from problems or life routines. Second was personal relationships, looked at in the form of social utility and relationship-building. Third was surveillance, defined as forms of seeking information. Fourth was personal identity, where the user consumes media to affirm their own sense of values or to explore the world around them (McQuail, Blumler, \& Brown, 1972). 
U\&G has not been without its critics, and some of those criticisms have come from those doing this type of research. The theory has been argued to be too broad, studying audience motivations, society, individual behavior, and culture among other things. The argument is the factors of use and motivation need to be more simplified (McQuail, 1994). In addition, critics charged that early research was based too much on self-reports and qualitative methods that were unconcerned about the unit of analysis' place among the population (Ruggiero, 2000).

Others have criticized U\&G theory as not being easily testable, or that this theory sees media use as being done in by its own parsimony, and that it violates its own tenets because a closer look at the data reveal that media use sometimes is not purposeful (Donohew, Nair, \& Finn, 1984; Kubey \& Csikszantmihalyi, 1990). Other findings directly contradict some of the assumptions central to $U \& G$ theory. Audiences have been shown to choose what they want to watch on television, for example, based on their mood, whereas another experiment that attempted to directly match content to audience needs in order to predict gratification also failed to find support (Stanford \& Riccomini, 1984; Zillmann \& Bryant, 1988).

In response to some of these criticisms, variables to measure different types of audience wants and needs have been developed from the beginnings laid by Blumler and Katz. Research has shown there are four gratifications typically accepted by researchers even if they are not broken into these four blocks all of the time: information, personal identity, integration and social interaction/entertainment (McQuail, 1994). 
While U\&G theory has proven to be a viable stream of research across media, it has been revived in online study in recent years because some scholars argue that the Internet is particularly suited for this type of theoretical approach due to the interactive nature of the medium that allows for greater levels of gratifications. The Internet has led to an explosion of media choices, and thus motivations for use become an important part of the puzzle related to use (Ruggiero, 2000). Those who read Web news are more likely to be newspaper readers, radio news listeners or television news viewers (Stempel III, Hargrove, \& Bernt, 2000). Usage of Internet sites strongly correlates with newspaper use, although it is not as strong for television use (Althaus \& Tewksbury, 2000). Subscribers to a local newspaper tend to comprise most of the online readership for that newspaper (Chyi \& Lasorsa, 1999), and in fact the vast majority of a newspaper's readers tend to come from the local market (Chyi \& Sylvie, 2001). Thus online news sites that target local readers would likely be most successful. High-volume users known as "power users" were more apt to use a traditional media source in addition to what is offered on the Web (Stempel III et al., 2000).

Studies have replicated the findings of other $U \& G$ researchers, finding that the four main gratifications from research in traditional media also correlated with Internet use (Kaye \& Johnson, 2002; Papacharissi \& Rubin, 2000). While noting that information is a gratification, it is worth considering whether "information-seeking" is a better way to describe the Internet medium because one can use it to both survey what is going on and find specific information on a topic of interest. 
Interactivity, in particular, has shown to be a key feature of Internet research. The interactive nature of the Internet medium has led to the blurring of the line between message sender and message receiver, and this opens up more avenues for research that do not exist for traditional media (Singer, 1998). Users identified social-enhancing gratifications in their Web use, such as the ability to continue relationships with people who live further away (Eighmey \& McCord, 1998). Internet news sites that capitalize on this interactive function rate well with users (Flanagin \& Metzger, 2001), and this has led to understanding that online media needed more interactive features to Web sites rather than featuring the "shovelware" concept of simply uploading all material from the print publication to a Web server and calling it an online product (Lin, 2001).

In addition, areas of $U \& G$ scholarship have caused some to rethink some of the theory's assumptions. One area being questioned is the notion of the active audience given that for a typical online offering some users are highly engaged and interactive while others are lurkers (Ha, 1995). Others have asserted the Web is the ultimate tool for the individual (Singer, 1998).

With all of the extra gratifications and avenues for research for $U \& G$ in online mass media, the need to identify workable models becomes a problem. Clearly the interactivity that comes with online media doesn't fit as neatly into U\&G research regarding traditional forms of media, as it could conceivably fit into more than one category (Ha \& James, 1998). One empirical study that attempted to group the variables more neatly found three more clear-cut gratifications that comes with Internet use: social gratifications, process gratifications, and content gratifications (Stafford, Stafford, \& 
Schkade, 2004). Content gratifications fill needs of consumption, that is that the content itself is what fills the need rather usage of the product. Process gratifications would involve factors of Internet use, such as killing time surfing the Web or the mere enjoyment of time spent online regardless of the content. Social gratifications cast a large net at all the interactive functions that come with online use, such as connection to community, connection to individuals, and access to knowledge about community affairs.

What is noteworthy about Stafford's approach is it is one of the first to make interactivity its own factor in Internet use. In their discussion they note that breaking up the $U \& G$ theory into this type of model has particular interest for research involving Internet and the building of online communities because there previously had been few models that isolated the interactivity factor (Stafford et al., 2004).

\section{Use of citizen journalism}

In applying the uses-and-gratifications theoretical framework to the concept of citizen journalism, it is worth noting a few studies done on citizen journalism from that perspective. Because it offers more interactivity than traditional news outlets, one can use a citizen journalism site in one of three ways: as a reader, as a writer, or as both (Ananny \& Strohecker, 2002; Bentley et al., 2005). This is an important distinction to make, because for the purposes of this study we will look beyond the traditional question of the relationship between media readership and political participation. When measuring the first part of our research question, the nature of the participatory function 
of citizen journalism, we will measure it from the point of view of those who perform one of these three functions, a point we will expand upon in the methods section.

The reason for setting aside this question is that media readership has consistently been tied to greater political participation, which is a component of civic engagement. Several studies, for example, have demonstrated a relationship between voting and newspaper readership (McCombs \& Pointdexter, 1983). The same has been done for television and the Internet, although both do not correlate as strongly as newspapers (Pointdexter \& McCombs, 2001). Thus the basis driving this research is that readership of citizen journalism also will positively correlate with production of social capital due to both the highly interactive nature of the medium itself as well as the ability the content has to draw social connections within the community for both readers and contributors.

One last point about citizen journalism research worth highlighting is that there have been surprising results in submissions. Political copy submission rates have been lower than expected at some sites, whereas story topics considered "softer" in some newspaper circles such as gardening, food, and religion have been areas that have seen greater rates of submission (Bentley et al., 2005). What this means is uncertain, but at the very least some of the assumptions about political content that have driven some citizen journalism startup sites might be called into question as the topic is studied further.

\section{Conclusions based on the literature}

The community organization aspect of social capital is seen as a major strength of the Internet, and the journalist's role in helping to direct that social capital toward the 
furthering of the public good (much in the same way public journalism attempts to do so) in the online sphere has not been fully explored (Uslaner, 2004).

At the same time, we know that online offerings present an opportunity for those looking to become more connected to others because of the interactive offerings made possible by this medium. The connectedness created through the shared online experience with other users could be the basis for the generation of social capital; that is that the medium can be used as a creator of the networks and norms necessary for social capital production. This is a key difference between the online medium and traditional mass media, which seem to merely point the way toward social connection rather than be an agent of social capital generation. In essence, the Internet can be a vehicle for both. A distinction that must be made, however, is that users are not interacting with the medium, but rather with others through the medium. This is critical to note in research because some interactive tools on the Web do not have a person on the other end of this "connection."

What is most interesting is whether use of a citizen journalism product correlates with higher levels social capital production than use of standard online news products such as a newspaper Web site. This study will adopt the Stafford model that examines process, content, and social gratifications as factors of Internet use. As noted in the literature, citizen journalism is in many ways a community-interest focused publication, because the stories and photography come directly from the community. It would seem that submitting to a citizen journalism Web site would tend to qualify as a type of civic engagement, especially since citizen journalism attempts to perform something akin to 
both the bridging and bonding role other online news sites perform. It should be expected that social gratifications would correlate with all of the factors of community involvement set forth by Shah.

Based on these ideas, the following hypotheses guided this research.

$\mathrm{H}_{1}$ : There will be a positive correlation between community involvement and the use of MyMissourian for interactivity.

Based on the literature, this result would make sense, because the best benefit of citizen journalism is its ability to be local in a socially-binding manner. Those who are involved in their communities would find more benefit from the social connections they make by using a publication such as MyMissourian. The publication allows the user to get to know their community and neighbors better, and that would seem to be of great interest to a user who already is highly involved in their community.

$\mathrm{H}_{2}$ : There will be a correlation between community involvement and the use of MyMissourian for content gratifications.

The expectation here is that the content on MyMissourian would be of interest to a person involved in the community because the content itself is community-oriented and highly local. It would seem that correlation would exist, but that it would not be as strong because we are predicting based on the first hypothesis that the main reason for using MyMissourian is for social connections.

$\mathrm{H}_{3}$ : Those who have written for MyMissourian will show differences in use for the purpose of interactivity compared with those who only read the site.

Writing in itself appears to be a participatory activity and would seem to fit well 
with McLeod's conceptual definition of community involvement. One who takes the step of going from a reader to a writer does so for the purpose of engaging their community in a greater way. In addition, MyMissourian gets a lot of copy from local political activists and concerned citizens, and it is expected that those types of users would be more involved politically.

$\mathrm{H}_{4}$ : Gratifications users derive from MyMissourian will combine with attitudinal direction to predict community involvement behavior.

What we are attempting to test with this hypothesis is the interaction of citizen journalism use with the attitudinal factors that help comprise the "virtuous circle of social capital". Interpersonal trust and life contentment comprise attitudes about self and community, whereas civic engagement is the indicator of social capital. What this would mean is that a person's use of a citizen journalism product would help spur the social capital production benefits that have been seen with use of other types of media.

In visual terms, the model would be mapped out as follows:

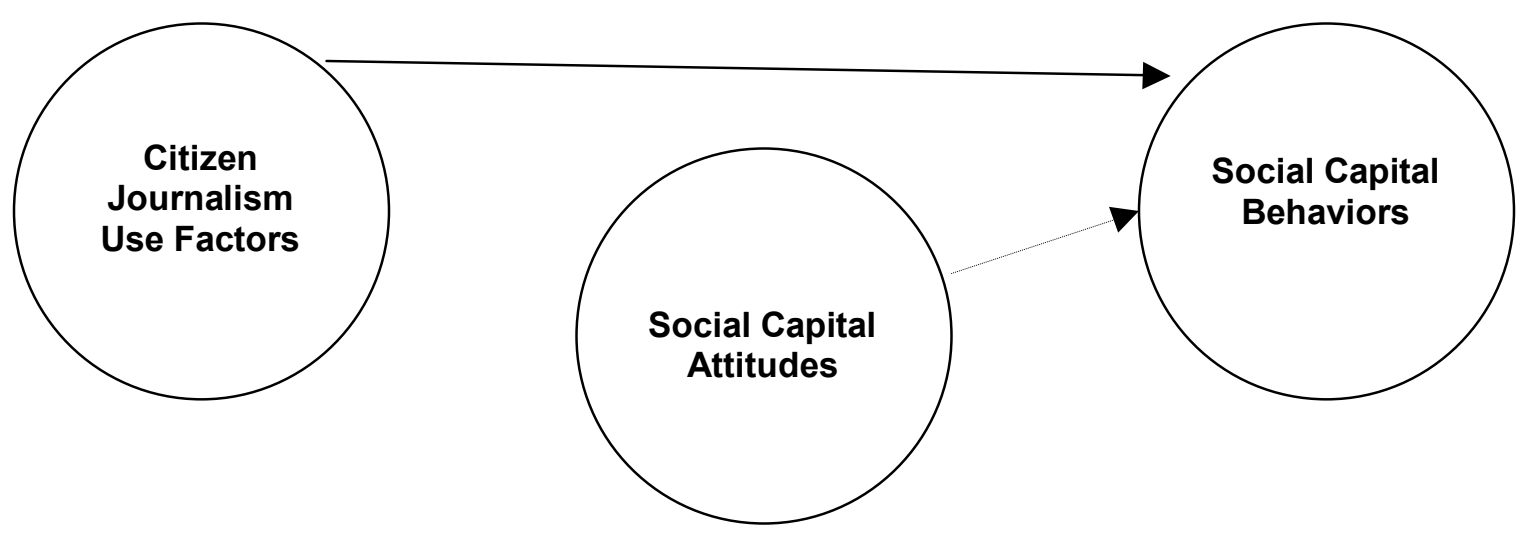

This model would predict that a strong sense of communication in community from the use of the MyMissourian product would make small predictions on behavior, but 
combining that with positive attitudes toward oneself and their community would make a better predictor. If the above model holds true, the behaviors predicted in the model would be those very behaviors that create social capital in communities: volunteerism, civic engagement, activism, voting, and neighbor relationships based on both sharing and caring. 


\section{METHOD}

This study uses an online survey method (See Appendix 1 for full questions) to attempt to find relationships between community involvement, a key element of social capital production, and the uses-and-gratifications of using citizen journalism either as a reader or as a contributor.

The survey indexes three elements of community involvement outlined in Shah's study: civic engagement, interpersonal trust, and life satisfaction (Shah et al., 2001), and these measures will serve as dependent variables. Civic engagement is conceptually defined as involvement in one's own community. It can include factors such as volunteer work, activism, churchgoing, or voting. Interpersonal trust is conceptually defined as trust in one's own community to live up to shared values and norms held by that community. Examples would include trusting a neighbor to stop kids from putting up graffiti in their neighborhood or working together to watch a person's house while they are on vacation. Life satisfaction in conceptual terms measures contentment with the current state of one's own life as well as the direction their life is going. These concepts were operationalized as 10 questions for each of these components and they can be viewed in Appendix 1, which shows the entire survey used in the study.

The survey also indexes three measures of Internet use consistent with the work of Stafford et. al.: social gratifications, content gratifications, and process gratifications (Stafford et al., 2004). These measures serve as independent variables. Content gratifications are conceptually defined as needs fulfilled by the consumption of the 
medium's actual messages, whereas process gratifications are conceptually defined as needs fulfilled by browsing the medium itself. Stafford makes the analogy that users sometimes gain enjoyment by the process of browsing the Web and seeing where it takes them (process gratifications) whereas other times they have needs fulfilled by specific site-related content. Social gratifications, which we are labeling "interactivity gratifications" for this study, are conceptually defined as needs fulfilled by the social connection and linkages that come with the social networking found within the medium. There were at least five questions for each measure and they can be viewed in Appendix 1 as well. Stafford notes that researchers have long understood the Internet as a communication tool capable of creating networks but that only recently have studies added the social networking element into research that looks at needs being fulfilled by online media.

Participants were registered users of MyMissourian.com, a citizen journalism Web site that is published in Columbia, Mo., as a companion publication to The Missourian, one of the city's newspapers.

Survey respondents were recruited in several ways. First, all of the registered users for MyMissourian were recruited via an informational e-mail. The registration database contained information on all users; many of the users have contributed to the site, and thus this pool of respondents is a natural group to solicit in this case. Second, an ad with a link to the survey was posted on MyMissourian's front page. Lastly, an ad was placed in the print edition advertising the survey. This brought in reader users, but it also 
attracted those who became familiar with MyMissourian's product only after the print launch.

All respondents were recruited with an offer to be entered in a drawing to win either an iPod shuffle or digital camera. One winner was drawn from the pool of those who completed the survey, and the winner had the option of selecting one of these two prizes. Those whose responses were not counted in the data analysis were still eligible for the drawing.

After entering the results, factor analysis was used to determine whether the variables measured sorted into variables as expected. A correlational t-test was performed in order to test the first two hypotheses. An independent samples test was used to determine for the third hypothesis to determine whether users of the site who had written an article reported higher levels of community involvement than those who had not written. Regression analysis was used to test various models for the fourth hypothesis 


\section{RESULTS}

For the purposes of data analysis, several responses were ignored because of the need to get the most representative sample of users. Those employed by the Missourian as well as those who worked on the MyMissourian project in the Missouri School of Journalism were removed from the sample. Because the goal of the research was to get an accurate picture of the user community, it did not make sense to include in the sample those involved in any way with the production of MyMissourian. The initial number of responses before those users were knocked out was 130, but 28 results were pared from the data table to yield a final $\mathrm{N}$ of 102 . In the end, the survey captured about $23 \%$ of total registered users for MyMissourian.

Factor analysis was used to verify the attitude variables (Table 1). Interpersonal trust (Cronbach's $\alpha=.87$ ) and life satisfaction questions (Cronbach's $\alpha=.78$ ) factored together. Civic engagement factored into three distinct categories, and conceptually they were labeled participation in community activities (Cronbach's $\alpha=.81$ ), working in the community (Cronbach's $\alpha=.80$ ), and activism in the community (Cronbach's $\alpha=.83$ ). Reliability results for these factors are shown in Table 2.

Factor analysis also was run on the items thought to compose the gratifications (Table 3). The items composing content gratifications (Cronbach's $\alpha=.85$ ) and process gratifications (Cronbach's $\alpha=.78$ ) were reliable. One of the content gratifications questions factored with interactivity as well. With a Cronbach's $\alpha=.87$, it was decided to group these questions together because of the conceptual fit for interactivity, and it also 
raised the reliability for both content gratifications and interactivity. Reliability results for these factors are shown in Table 4.

A separate analysis also showed that all of the factors of the independent variable gratifications were highly correlated with one another (Table 6) meaning that these factors of gratifications were multicollinear.

Hypothesis 1 predicted there would be a positive correlation between community involvement and the use of MyMissourian for interactivity. This hypothesis was supported, as interactivity correlated highly on all five factors of community involvement. Interactivity correlations were highly significant $(\mathrm{p}<.01)$ with interpersonal trust, community activity participation, and working in the community (Table 5). Correlation was significant $(\mathrm{p}<.05)$ with activism in the community and life contentment.

Hypothesis 2 predicted there would be a correlation between community involvement and the use of MyMissourian for content gratifications. This hypothesis was not supported, although content gratifications did correlate with four of the five factors of community involvement (Table 5). Content gratifications was highly correlated interpersonal trust as well as with life contentment, working in the community, and activism in the community.

Hypothesis 3 predicted that those who have written for MyMissourian would show differences in use for the purpose of interactivity compared with those who only read the site. This hypothesis was not supported. Of the 102 respondents, 69 reported having written for the site compared with 33 who had not. Actually, looking at the differences for each variable in the study between writers and non-writers, only four 
variables showed marginally significant differences: interactivity gratifications (mean for writers $=3.50$ on a 5 -point scale; for non-writers $=3.30, \mathrm{t}=1.713, \mathrm{p}<.10$ ); process gratifications $($ mean for writers $=2.90$; for non-writers $=3.17, \mathrm{t}=1.830, \mathrm{p}<.08$ ); content gratifications $($ mean for writers $=3.39$; for non-writers $=3.63, \mathrm{t}=1.791, \mathrm{p}<.09$ ); the dependent variable activism in the community $($ mean for writers $=2.15$; for non-writers $=$ $1.86, \mathrm{t}=-1.940, \mathrm{p}<.07)$. The mean scores for this test are found in Table 8 and the results of the independent samples $t$ test are found in Table 9.

Hypothesis 4 predicted that gratifications users derive from MyMissourian along with the attitudinal variables will predict the three measures of community involvement behavior (activism in community, working in community, community activity participation). To test this, a series of hierarchical regressions were executed. In the first block, demographics were entered. In the second block the attitudinal variables were entered, and in the third, the three types of gratifications were entered.

The results (shown in Tables 10-12) were highly supportive of the hypothesis. In the final model predicting communication activity, married people were more likely to be active. Interpersonal trust, and process gratifications were the only two variables that were significant, with the overall model accounting for $23 \%$ of the variance. In the final model predicting working the community, none of the demographics were significant.

Again, interpersonal trust was the major predictor. Process gratifications were marginally significant. The overall model predicted $30 \%$ of the variance. In the final model for activism in the community, none of the demographics were significant, and trust again emerged as the single significant variable, accounting for $7 \%$ of the variance. 


\section{DISCUSSION}

What was found was a model that shows prediction of social capital in the form of civic engagement, which can be measured along participation, volunteering, and activism. It bears repeating that these measures of civic engagement could be viewed as progressive steps starting with participation and ending with activism.

In hindsight the results seem to make much more sense with the newer model than the original model, which hoped that high scores for interactivity gratifications would be a predictor of social capital creation. While Shah did offer his three factors of community involvement (interpersonal trust, life contentment, and civic engagement), it seems much more probable that the third element of civic engagement is the actual measure of the creation of social capital. By grouping trust and contentment into attitudes, it seems that this facet of community involvement could act more as a conduit to or feeder for the creation of social capital than social capital itself. One implication of this finding is that perhaps social capital research, which has already found this element of prediction in the virtuous circle model, should focus on ways in which people acquire a better sense of life contentment and interpersonal trust.

The multiple regression analyses seemed to at least predict this and show that attitudes were a factor in predicting social capital creation. But it is unknown whether the unique nature of MyMissourian is creating social capital or attracting those who are social capital creators. While the model does show prediction, what is not known is whether there is causality. It could be that users are coming to the site and contributing to 
it because it meets their goals of activism or service in the community, and in that case MyMissourian is more of a place for social capital creators to coalesce. On the other hand, MyMissourian might be a tool that gratifies the needs of users, and that in addition to life contentment combine as factors of social capital creation.

What made the analysis even more surprising was that interactivity gratifications were the only factor of use to correlate with patterns of community involvement. Content gratifications nearly correlated, but process gratifications only correlated on three of the five involvement factors. Thus it was assumed that because interactivity correlated so highly that correlation would be a strong predictor of community involvement in the regression analysis as well. In the end the co-linearity of the three use dimensions was a critical reason for making us rethink the data analysis. In a way this makes sense given the model that Stafford set up for his online U\&G model, because in coming up with three categories it is easy to see that some gratifications might overlap into two categories. For example, it is difficult to ask someone about their experiences with MyMissourian without talking about community. Thus content questions could also be interactivity questions.

Stafford's model indicates some sort of answer to the critics' charges that there are too many factors and that sorting items such as motivation and gratifications into neatly divided categories ignores the complex nature that comes with making a choice. In that sense, perhaps co-linearity should not be viewed as a surprise and shows that in this model the emphasis is not on what the user is getting out of the product but rather 
what the use tells us about other variables (in this case, the creation of social capital in a community).

Perhaps the most surprising result was that there was no statistically significant difference between writers and readers on any of the measures, whether it was use or community involvement. Based on the literature it seems plausible to think the act of taking the extra step to contribute to MyMissourian would result in higher mean scores for both interactivity gratifications as well as several (if not all) of the community involvement variables. The analysis showed no statistically significant differences between the groups on any of the factors (see Appendix 2), although activism was approaching significance at $\mathrm{p}<0.058$.

There could be several explanations for this worth testing. One possible reason is because content gratifications nearly had correlation with all the facets of community involvement as well, and this might indicate that the content itself gives the reader as much satisfaction as the interactive process of writing gives the contributor. Another could be that we are thinking about contributing in the wrong way, that perhaps it is not an act in a similar vein to volunteerism or activism because the person is promoting something from their own life or line of work rather than a cause or idea that has community-wide benefits. Some of the content contributed on MyMissourian is certainly not activist-oriented in quality, with topics ranging from recipes to gardening tips.

Another avenue worth exploring would be to do a deeper analysis of what it means to be politically active in the community. While social capital does focus on behaviors and attitudes, it seems that much of the research tends to have voting behaviors 
as a goal. Perhaps people in communities are taking a much more broad definition of political involvement; that is, perhaps the act of volunteering, cleaning up a community, or having neighbors over for dinner is, in a sense, a political act unto itself. After all, it is a community bonding type of activity, and some social capital thinkers have noted that the small connections between people make communities functions in ways that mere voting cannot account for.

\section{Limitations of This Research}

This study had some limitations. To begin with, conducting this study in a town such as Columbia has the potential pitfalls for any research seeking to generalize based on one study. It has been said more than once that Columbia is the most "over-covered" town in the United States due to the presence of the journalism school. With media saturation so high and a steady lineup of media products for the local resident, it is difficult to account for this as a confounding variable. Perhaps residents here are trained to get more from their media, or perhaps media literacy in Columbia is higher than it is for other cities and thus it is consumed in a different manner than it would be somewhere else. This is not to say Columbia is a unique in ways that invalidate the research, but it does mean that good research that attempts to build on these results must try to account for these problems as the research questions bring about more studies.

Secondly, the nature of the sample used is not random due to the fact that it was an online survey. In terms of methodology, this was accounted for by eliminating responses from Missourian faculty as well as students who worked on the project. In 
addition, part of the method involved going through the list of registered users (the source solicited in the survey itself) in order to eliminate the above types of users as well as problematic factors such as duplicate registrations. While it was difficult to account for all of these things consistently with such a large database, the denominator in the final tally was 473 people in the database, meaning that we surveyed $21.56 \%$ of the population. It is worth noting that if we were to run the same method in paring down the database today the number would be well over 600 people, but the database we worked with in terms of solicitation for the survey was specifically based on the date the survey was released.

One final limitation is that the users being surveyed were essentially what is known as "early adopters." This term is used to describe people who will take advantage of a new technology when it is first offered, an indication of their own confidence and sense of efficacy with new technology offerings. As such, this group might test differently than a more representative group once the site has been given a few years to mature.

\section{Future Research}

There are several ways in which to build upon this study. The most obvious to come from the analysis and conclusions is that it is unknown whether the model that combines use and attitudes as predictors of civic engagement (social capital) are causal. There are several ways in which this could be tested, and one of them would be to design 
and experiment that pretests and posttests civic engagement around a new citizen journalism product in a place that has not yet seen the product implemented.

It would seem that the biggest obstacle to such an extension of this research would be the amount of confounding variables that could be encountered. Recall that one of the criticisms of the $U \& G$ model is that there were simply too many variables of wants and needs to be measured. Stafford's model might present a more simplified way of testing the theory and could prove useful in any experiment that attempts to find causality, but it also throws out other factors of Web use such as non-news or community needs fulfilled such as shopping.

Another interesting way to expand on these results might be to test this model with other online products that are not citizen-journalism oriented. Two questions that looked at demographic data showed that of the 102 respondents used in this analysis, only $18.6 \%$ reported being a subscriber to the Missourian, which publishes MyMissourian, and $76.5 \%$ reported having a subscription to the Columbia Daily Tribune. Subscriptions are not the only way of measuring readership though, as $44.1 \%$ reported reading the Missourian either "often" or "very often" compared to $41.2 \%$ for the Tribune.

Given that data, it is difficult to predict whether the MyMissourian audience represents a different and more-engaged readership than what the newspapers in town currently have. Thus it would seem that, as suggested earlier, trying to replicate this study across different forms of media would be interesting. Of course, one limitation of this approach is it assumes a fractured approach to media research. By studying them individually, it would ignore the possibility that some use all forms of media, and often 
times several forms at the same time (the notion of a person surfing the Internet while watching television is not implausible).

Another more logical extension of this study would be to attempt to isolate those interactivity gratifications that correlated so highly with factors of community involvement. In an attempt to not make the survey too long, it is clear that more surveys that look more intently at that part of use might yield more clarification on the issue. As stated in the literature review, Internet $U \& G$ research looked at interactivity in terms of social networking, connectivity, discussion, and interpersonal networks. It is expected that many of the same factors found in interactivity research would be found if more examination of interactivity gratifications were to be undertaken.

In addition, it would be worthwhile to examine a potential hole in interactivity research. There might be differences between a type of interactivity that has somebody interacting with a machine or Web server (such as instant polls) as opposed to people who interact with other people through tools such as chat boards. While citizen journalism offers a computer-mediated form of interactivity, at its core is still a premium that is placed on interacting with people. 


\section{DATA TABLES}

\section{TABLE 1: Rotated Component Matrix for Community Involvement}

\begin{tabular}{|c|c|c|c|c|}
\hline & \multicolumn{4}{|c|}{ Component } \\
\hline & $\begin{array}{c}\text { Content } \\
\text { Gratifications }\end{array}$ & $\begin{array}{c}\text { Interactivity } \\
\text { Gratifications }\end{array}$ & $\begin{array}{c}\text { Process } \\
\text { Gratifications }\end{array}$ & Connectivity \\
\hline Content: Learn about community & .819 & .140 & .252 & .198 \\
\hline Content: Learn about neighbors & .704 & .213 & .351 & .002 \\
\hline Content: Unique content & .774 & .136 & .029 & .235 \\
\hline Content: Add to knowledge about comm. & .873 & .192 & .164 & .143 \\
\hline Content: Being informed & .752 & .298 & .266 & .621 \\
\hline Social: Community knowledge base & .473 & .562 & .126 & .313 \\
\hline Social: Know people in community & .401 & .708 & -.018 & .278 \\
\hline Social: What is going on & .275 & .775 & .188 & .283 \\
\hline Social: Meet people & .067 & .781 & .273 & .089 \\
\hline Interactivity: Interactive format & .315 & .649 & .324 & .158 \\
\hline Interactivity: Ability to respond & .346 & .548 & .361 & -.212 \\
\hline Process: Search for articles & .170 & .094 & .781 & -.072 \\
\hline Process: Spend time serving & .268 & .151 & .539 & .165 \\
\hline Process: Appealing use of technology & -.124 & .040 & .739 & .340 \\
\hline Connectivity: Feel like part of comm.. & .226 & .597 & .188 & .614 \\
\hline Connectivity: New ways to interact & .335 & .578 & .112 & .705 \\
\hline
\end{tabular}

Extraction Method: Principal Component Analysis.

\section{TABLE 2: Reliability Test For Community Involvement Scales}

\begin{tabular}{|l|r|r|}
\hline Factor & \multicolumn{1}{|c|}{$\begin{array}{c}\text { Cronbach's } \\
\text { Alpha }\end{array}$} & \multicolumn{1}{|c|}{$\begin{array}{c}\text { N of } \\
\text { Items }\end{array}$} \\
\hline Interpersonal Trust & .865 & 7 \\
Life Contentment & .779 & 4 \\
Community Activities Participation & .811 & 6 \\
Working in the Community & .797 & 5 \\
Activism in the Community & .832 & 2 \\
\hline
\end{tabular}


TABLE 3: Rotated Component Matrix (a) for Gratifications

\begin{tabular}{|c|c|c|c|c|}
\hline & \multicolumn{4}{|c|}{ Component } \\
\hline & $\begin{array}{c}\text { Content } \\
\text { Gratifications }\end{array}$ & $\begin{array}{c}\text { Social } \\
\text { Gratifications } \\
\text { (Connectivity) }\end{array}$ & $\begin{array}{c}\text { Process } \\
\text { Gratifications }\end{array}$ & Interactivity \\
\hline Content Gratifications 1 & .819 & .140 & .252 & .198 \\
\hline Content Gratifications 2 & .704 & .213 & .351 & .002 \\
\hline Content Gratifications 3 & .774 & .136 & .029 & .235 \\
\hline Content Gratifications 4 & .873 & .192 & .164 & .143 \\
\hline Content Gratifications 5 & .752 & .298 & .266 & .621 \\
\hline Content Gratifications 6 & .473 & .562 & .126 & .313 \\
\hline Social Gratifications 1 & .401 & .708 & -.018 & .278 \\
\hline Social Gratifications 2 & .275 & .775 & .188 & .283 \\
\hline Social Gratifications 3 & .067 & .781 & .273 & .089 \\
\hline sSocial Gratifications 4 & .315 & 649 & .324 & .158 \\
\hline Social Gratifications 5 & .346 & .548 & .361 & -.212 \\
\hline Process Gratifications 1 & .170 & .094 & .781 & -.072 \\
\hline Process Gratifications 2 & .268 & .151 & .539 & .165 \\
\hline Process Gratifications 3 & -.124 & .040 & .739 & .340 \\
\hline DVUseConnectivity1 & .226 & .597 & .188 & .614 \\
\hline DVUseConnectivity2 & .335 & .578 & .112 & .705 \\
\hline
\end{tabular}

Extraction Method: Principal Component Analysis.

Rotation Method: Varimax with Kaiser Normalization.

a Rotation converged in 7 iterations.

\section{TABLE 4: Reliability Test For Gratifications Scales}

\begin{tabular}{|l|r|r|}
\hline Factor & $\begin{array}{c}\text { Cronbach's } \\
\text { Alpha }\end{array}$ & $\begin{array}{c}\text { N of } \\
\text { Items }\end{array}$ \\
\hline Content Gratifications & .847 & 5 \\
Social Gratifications (Connectivity) & .865 & 8 \\
Process Gratifications & .784 & 3 \\
\hline
\end{tabular}


TABLE 5: Correlation of IV (Gratifications) to DV (Community Involvement)

\begin{tabular}{|c|c|c|c|c|c|c|}
\hline & & $\begin{array}{c}\text { Interpersonal } \\
\text { Trust }\end{array}$ & $\begin{array}{c}\text { Life } \\
\text { Contentment }\end{array}$ & $\begin{array}{c}\text { CE: } \\
\text { Community } \\
\text { Activity } \\
\text { Participation } \\
\end{array}$ & $\begin{array}{l}\text { CE: Working } \\
\text { in Community }\end{array}$ & $\begin{array}{l}\text { CE: Activism } \\
\text { in Community }\end{array}$ \\
\hline \multirow{3}{*}{$\begin{array}{l}\text { Content } \\
\text { Gratifications }\end{array}$} & $\begin{array}{l}\text { Pearson } \\
\text { Correlation }\end{array}$ & $.255(* *)$ & $.239(*)$ & .147 & $.202(*)$ & $.241\left(^{*}\right)$ \\
\hline & $\begin{array}{l}\text { Sig. (2- } \\
\text { tailed) }\end{array}$ & .010 & .016 & .139 & .041 & .015 \\
\hline & $\mathrm{N}$ & 102 & 102 & 102 & 102 & 102 \\
\hline \multirow[t]{3}{*}{ Interactivity } & $\begin{array}{l}\text { Pearson } \\
\text { Correlation }\end{array}$ & $.296(* *)$ & $.230(*)$ & $.257(* *)$ & $.297(* *)$ & $.203(*)$ \\
\hline & $\begin{array}{l}\text { Sig. (2- } \\
\text { tailed) }\end{array}$ & .003 & .020 & .009 & .002 & .040 \\
\hline & $\mathrm{N}$ & 102 & 102 & 102 & 102 & 102 \\
\hline \multirow[t]{3}{*}{$\begin{array}{l}\text { Process } \\
\text { Gratifications }\end{array}$} & $\begin{array}{l}\text { Pearson } \\
\text { Correlation }\end{array}$ & .142 & .174 & $.324(* *)$ & $.312(* *)$ & .081 \\
\hline & $\begin{array}{l}\text { Sig. (2- } \\
\text { tailed) }\end{array}$ & .153 & .080 & .001 & .001 & .416 \\
\hline & $\mathrm{N}$ & 102 & 102 & 102 & 102 & 102 \\
\hline
\end{tabular}

** Correlation is significant at the 0.01 level (2-tailed).

* Correlation is significant at the 0.05 level (2-tailed).

\section{TABLE 6: Correlation of Independent Variable Factors}

\begin{tabular}{|c|c|c|c|c|}
\hline & & $\begin{array}{c}\text { Content } \\
\text { Gratifications }\end{array}$ & Interactivity & $\begin{array}{c}\text { Process } \\
\text { Gratifications }\end{array}$ \\
\hline \multirow[t]{3}{*}{ Content Gratifications } & Pearson Correlation & 1 & $.850(* *)$ & $.451(* *)$ \\
\hline & Sig. (2-tailed) & & .000 & .000 \\
\hline & $\mathrm{N}$ & 102 & 102 & 102 \\
\hline \multirow[t]{3}{*}{ Interactivity } & Pearson Correlation & $.850(* *)$ & 1 & $.566(* *)$ \\
\hline & Sig. (2-tailed) & .000 & & .000 \\
\hline & $\mathrm{N}$ & 102 & 102 & 102 \\
\hline \multirow[t]{3}{*}{ Process Gratifications } & Pearson Correlation & $.451(* *)$ & $.566(* *)$ & 1 \\
\hline & Sig. (2-tailed) & .000 & .000 & \\
\hline & $\mathrm{N}$ & 102 & 102 & 102 \\
\hline
\end{tabular}

** Correlation is significant at the 0.01 level (2-tailed).

- Correlation is significant at the 0.05 level (2-tailed). 
TABLE 7: Correlation of Dependent Variable Factors

\begin{tabular}{|c|c|c|c|c|c|c|}
\hline & & $\begin{array}{c}\text { Interpersonal } \\
\text { Trust }\end{array}$ & $\begin{array}{c}\text { Life } \\
\text { Contentment }\end{array}$ & $\begin{array}{c}\text { CE: } \\
\text { Community } \\
\text { Activity } \\
\text { Participation }\end{array}$ & $\begin{array}{l}\text { CE: } \\
\text { Working in } \\
\text { Community }\end{array}$ & $\begin{array}{c}\text { CE: } \\
\text { Activism in } \\
\text { Community }\end{array}$ \\
\hline \multirow[t]{3}{*}{$\begin{array}{l}\text { Interpersonal } \\
\text { Trust }\end{array}$} & $\begin{array}{l}\text { Pearson } \\
\text { Correlation }\end{array}$ & 1 & .084 & $.332(* *)$ & $.438(* *)$ & .101 \\
\hline & $\begin{array}{l}\text { Sig. (2- } \\
\text { tailed) }\end{array}$ & & .400 & .001 & .000 & .313 \\
\hline & $\mathrm{N}$ & 102 & 102 & 102 & 102 & 102 \\
\hline \multirow[t]{3}{*}{$\begin{array}{l}\text { Life } \\
\text { Contentment }\end{array}$} & $\begin{array}{l}\text { Pearson } \\
\text { Correlation }\end{array}$ & .084 & 1 & .059 & .190 & $.247(*)$ \\
\hline & & .400 & & .557 & .056 & .012 \\
\hline & $\mathrm{N}$ & 102 & 102 & 102 & 102 & 102 \\
\hline \multirow{3}{*}{$\begin{array}{l}\text { CE: Community } \\
\text { Activity } \\
\text { Participation }\end{array}$} & $\begin{array}{l}\text { Pearson } \\
\text { Correlation }\end{array}$ & $.332(* *)$ & .059 & 1 & $.573(* *)$ & $.400(* *)$ \\
\hline & $\begin{array}{l}\text { Sig. (2- } \\
\text { tailed) }\end{array}$ & .001 & .557 & & .000 & .000 \\
\hline & $\mathrm{N}$ & 102 & 102 & 102 & 102 & 102 \\
\hline \multirow[t]{3}{*}{$\begin{array}{l}\text { CE: Working in } \\
\text { Community }\end{array}$} & $\begin{array}{l}\text { Pearson } \\
\text { Correlation }\end{array}$ & $.438(* *)$ & .190 & $.573(* *)$ & 1 & $.448(* *)$ \\
\hline & $\begin{array}{l}\text { Sig. (2- } \\
\text { tailed) }\end{array}$ & .000 & .056 & .000 & & .000 \\
\hline & $\mathrm{N}$ & 102 & 102 & 102 & 102 & 102 \\
\hline \multirow[t]{3}{*}{$\begin{array}{l}\text { CE: Activism in } \\
\text { Community }\end{array}$} & $\begin{array}{l}\text { Pearson } \\
\text { Correlation }\end{array}$ & . 101 & $.247(*)$ & $.400(* *)$ & $.448(* *)$ & 1 \\
\hline & $\begin{array}{l}\text { Sig. (2- } \\
\text { tailed) }\end{array}$ & .313 & .012 & .000 & .000 & \\
\hline & $\mathrm{N}$ & 102 & 102 & 102 & 102 & 102 \\
\hline
\end{tabular}

** Correlation is significant at the 0.01 level (2-tailed).

* Correlation is significant at the 0.05 level (2-tailed). 
TABLE 8: Means for Writers vs. Readers for Gratifications and Community Involvement

\begin{tabular}{|l|l|r|r|r|r|}
\hline & $\begin{array}{l}\text { Write for My } \\
\text { Missourian? }\end{array}$ & $\mathrm{N}$ & \multicolumn{1}{c|}{ Mean } & Std. Deviation & $\begin{array}{c}\text { Std. Error } \\
\text { Mean }\end{array}$ \\
\hline Content Gratifications & No & 33 & 18.1515 & 2.63535 & .45876 \\
& Yes & 69 & 16.9710 & 3.93316 & .47350 \\
Interactivity & No & 33 & 28.0303 & 3.69531 & .64327 \\
& Yes & 69 & 26.4058 & 5.79127 & .69719 \\
Process Gratifications & No & 33 & 9.5152 & 1.82211 & .31719 \\
& Yes & 69 & 8.7246 & 2.43675 & .29335 \\
Interpersonal Trust & No & 33 & 23.3030 & 5.07743 & .88387 \\
& Yes & 69 & 22.3333 & 5.79469 & .69760 \\
Life Contentment & No & 33 & 5.1515 & 1.73424 & .30189 \\
& Yes & 69 & 5.5942 & 1.88897 & .22741 \\
CE: Community Activity Participation & No & 33 & 14.0909 & 3.69428 & .64309 \\
& Yes & 69 & 13.9565 & 4.58076 & .55146 \\
CE: Working in Community & No & 33 & 9.8788 & 2.35528 & .41000 \\
& Yes & 69 & 10.2319 & 3.68281 & .44336 \\
CE: Activism in Community & No & 33 & 3.7273 & 1.28142 & .22307 \\
& Yes & 69 & 4.3188 & 1.72774 & .20800 \\
\hline
\end{tabular}

TABLE 9: Writers vs. Readers for Gratifications and Community Involvement (independent samples $t$ test)

\begin{tabular}{|c|c|c|c|c|c|c|}
\hline & & $\mathrm{t}$ & $\mathrm{df}$ & $\begin{array}{c}\text { Sig. } \\
(2- \\
\text { tailed })\end{array}$ & $\begin{array}{l}95 \% \mathrm{Cc} \\
\text { Interv } \\
\text { Diffe }\end{array}$ & $\begin{array}{l}\text { dence } \\
\text { of the } \\
\text { ace }\end{array}$ \\
\hline & & & & & Lower & Upper \\
\hline Content Gratifications & Equal variances assumed & 1.563 & 100 & .121 & -.31839 & 2.67939 \\
\hline & Equal variances not assumed & 1.791 & 88.976 & .077 & -.12949 & 2.49049 \\
\hline Interactivity & Equal variances assumed & 1.472 & 100 & .144 & -.56450 & 3.81351 \\
\hline & Equal variances not assumed & 1.713 & 91.754 & .090 & -.25959 & 3.50860 \\
\hline Process Gratifications & Equal variances assumed & 1.654 & 100 & .101 & -.15778 & 1.73881 \\
\hline & Equal variances not assumed & 1.830 & 81.942 & .071 & -.06897 & 1.65000 \\
\hline Interpersonal Trust & Equal variances assumed & .822 & 100 & .413 & -1.37138 & 3.31077 \\
\hline & Equal variances not assumed & .861 & 71.270 & .392 & -1.27533 & 3.21472 \\
\hline Life Contentment & Equal variances assumed & -1.136 & 100 & .259 & -1.21568 & .33031 \\
\hline & Equal variances not assumed & -1.171 & 68.273 & .246 & -1.19684 & 31146 \\
\hline $\begin{array}{l}\text { CE: Community Activity } \\
\text { Participation }\end{array}$ & Equal variances assumed & .147 & 100 & .883 & -1.67833 & 1.94710 \\
\hline & Equal variances not assumed & .159 & 76.817 & .874 & -1.55258 & 1.82136 \\
\hline CE: Working in Community & Equal variances assumed & -.503 & 100 & .616 & -1.74565 & 1.03946 \\
\hline & Equal variances not assumed & -.585 & 91.632 & .560 & -1.55251 & .84632 \\
\hline $\begin{array}{l}\text { CE: Activism in } \\
\text { Community }\end{array}$ & Equal variances assumed & -1.748 & 100 & .083 & -1.26280 & .07967 \\
\hline & Equal variances not assumed & -1.940 & 82.489 & .056 & -1.19824 & .01511 \\
\hline
\end{tabular}


TABLE 10: Final Model Predicting Community Activity Participation

\begin{tabular}{|c|c|c|c|c|c|c|}
\hline \multirow[t]{2}{*}{ Model } & & \multicolumn{2}{|c|}{$\begin{array}{l}\text { Unstandardized } \\
\text { Coefficients }\end{array}$} & \multirow{2}{*}{$\begin{array}{c}\text { Standardized } \\
\text { Coefficients } \\
\text { Beta }\end{array}$} & \multirow[t]{2}{*}{$\mathrm{t}$} & \multirow[t]{2}{*}{ Sig. } \\
\hline & & $\mathrm{B}$ & Std. Error & & & \\
\hline \multirow[t]{11}{*}{3} & (Constant) & 2.879 & 3.947 & & .730 & .468 \\
\hline & Age & .224 & .200 & .139 & 1.124 & .264 \\
\hline & Gender & .582 & .902 & .062 & .646 & .520 \\
\hline & Marital Status & 2.173 & .948 & .254 & 2.293 & $.024(*)$ \\
\hline & Education & -.537 & .496 & -.111 & -1.082 & .282 \\
\hline & Income & .040 & .200 & .023 & .199 & .843 \\
\hline & Interpersonal Trust (DV) & .198 & .074 & .257 & 2.670 & $.009(* *)$ \\
\hline & Life Contentment (DV) & .014 & .212 & .006 & .065 & .949 \\
\hline & Content Gratifications (IV) & -.278 & .208 & -.232 & -1.335 & .185 \\
\hline & Interactivity Gratifications (IV) & .199 & .152 & .243 & 1.312 & .193 \\
\hline & Process Gratifications (IV) & .450 & .214 & .239 & 2.103 & $.038(*)$ \\
\hline
\end{tabular}

$\left(r^{2}=.304\right.$, adjusted $\left.r^{2}=.228\right)$

\section{TABLE 11: Final Model Predicting Working in Community}

\begin{tabular}{|c|c|c|c|c|c|c|}
\hline \multirow[t]{2}{*}{ Model } & & \multicolumn{2}{|c|}{$\begin{array}{l}\text { Unstandardized } \\
\text { Coefficients }\end{array}$} & \multirow{2}{*}{$\begin{array}{c}\text { Standardized } \\
\text { Coefficients }\end{array}$} & \multirow[t]{2}{*}{$\mathrm{t}$} & \multirow[t]{2}{*}{ Sig. } \\
\hline & & $\mathrm{B}$ & Std. Error & & & \\
\hline \multirow[t]{11}{*}{3} & (Constant) & 1.987 & 2.888 & & .688 & .493 \\
\hline & Age & .236 & .146 & .190 & 1.618 & .109 \\
\hline & Gender & -.755 & .660 & -.105 & -1.144 & .255 \\
\hline & Marital Status & .408 & .694 & .062 & .588 & .558 \\
\hline & Education & -.241 & .363 & -.065 & -.664 & .508 \\
\hline & Income & .118 & .146 & .089 & .807 & .422 \\
\hline & Interpersonal Trust (DV) & .205 & .054 & .346 & 3.781 & $.000(* *)$ \\
\hline & Life Contentment (DV) & .255 & .155 & .142 & 1.640 & .104 \\
\hline & Content Gratifications (IV) & -.119 & .152 & -.130 & -.784 & .435 \\
\hline & Interactivity Gratifications (IV) & .094 & .111 & .150 & .848 & .399 \\
\hline & Process Gratifications (IV) & .278 & .157 & .192 & 1.775 & .079 \\
\hline
\end{tabular}

$\left(r^{2}=.370\right.$, adjusted $\left.r^{2}=.301\right)$ 
TABLE 12: Final Model Predicting Activism in Community

\begin{tabular}{|l|l|r|r|r|r|r|}
\hline \multirow{2}{*}{ Model } & & \multicolumn{2}{|c|}{$\begin{array}{c}\text { Unstandardized } \\
\text { Coefficients }\end{array}$} & \multicolumn{2}{c|}{$\begin{array}{c}\text { Standardized } \\
\text { Coefficients }\end{array}$} & $\mathrm{t}$ \\
\hline & & \multicolumn{1}{c|}{$\mathrm{B}$} & Std. Error & Beta & & \\
\hline 3 & (Constant) & .593 & 1.632 & & .364 & .717 \\
& Age & .129 & .083 & .213 & 1.569 & .120 \\
& Gender & .304 & .373 & .086 & .816 & .417 \\
& Marital Status & -.278 & .392 & -.087 & -.710 & .479 \\
& Education & .030 & .205 & .017 & .149 & .882 \\
& Income & .080 & .083 & .124 & .969 & .335 \\
& Interpersonal Trust (DV) & -.011 & .031 & -.036 & -.345 & .731 \\
& Life Contentment (DV) & .187 & .088 & .214 & 2.138 & .035 \\
& Content Gratifications (IV) & .137 & .086 & .304 & 1.591 & .115 \\
& Interactivity Gratifications (IV) & .002 & .063 & .005 & .025 & .980 \\
& Process Gratifications (IV) & -.075 & .088 & -.106 & -.854 & .396 \\
\hline
\end{tabular}

$\left(r^{2}=.158\right.$, adjusted $\left.r^{2}=.066\right)$ 


\section{APPENDIX}

Survey Questions

\section{Civic Engagement Questions (DV)}

In this section you will be asked about some of your everyday activities. Answer the question by indicating how often you participate in the activity described (Never to Very Often, 4-point scale)

“Community Activity Participation” questions

- Help neighbors when they are in need.

- Take care of your neighbors' children.

- Attend religious services.

- Work on activities through your local church or other religious organization.

- Vote in local elections.

- Give away items to those in need within my community as part of local drives.

"Working in the Community" questions

- Donate time to work for a community organization.

- Pick up trash in my neighborhood.

- Use my unique skills or talents in a way that helps people in my neighborhood.

- Work on projects which beautify my neighborhood.

- Work for a local charity.

“Activism in Community" questions

- Attend meetings centered around a topic of interest.

- Speak up at meetings centered around a topic of interest.

\section{Interpersonal Trust Questions (DV)}

In this section there are a number of statements about interests and opinions. For each statement listed, indicate the degree to which you agree or disagree with the statement. (5-point Likert scale)

- I would allow most people in my neighborhood to watch my children (assuming I have children).

- I would lend a favorite possession to someone who lived next door to me.

- I would have no hesitation about exchanging keys to one's home with a neighbor.

- I think I generally can trust my neighbors to help me in times of need.

- I think someone in my community would call the police if they found suspicious activity outside of my house while I was away.

- Parents in my community would likely step in if they saw that children were skipping school. 
- My neighbors would be likely to put a stop to a fight breaking out in front of my house

\section{Life Contentment Questions (DV)}

In this section there are a number of statements about interests and opinions. For each statement listed, indicate the degree to which you agree or disagree with the statement. (5-point Likert scale)

- I am very satisfied with the way things are going in my life these days

- I wish I could change my present life and do something entirely different

- Sometimes I feel that I don't have enough control over the direction my life is taking

- I spend adequate amounts of time doing things I enjoy

\section{Citizen Journalism Gratifications Questions (IV)}

In this section I will ask you about some of your use of MyMissourian.com. For each statement listed, indicate the degree to which you agree or disagree with the statement. (5-point Likert scale)

“Content Gratifications" questions

- I want to learn more about my community.

- I want to learn more about my neighbors.

- The site contains material I cannot find anywhere else.

- I like knowing more about my community.

- It is important to be informed about what is going on in my community.

"Interactivity Gratifications" questions

- The site is a database of community knowledge.

- I want to get to know people in my community.

- I am interested in what is going on in my community.

- I get to meet people in my community in the real world because of content on the site.

- I like the interactive format that MyMissourian brings.

- The site offers the ability to reply and interact with posted content.

- The site makes me feel like I am part of a community. (collapsed from connectivity questions)

- The site gives me new ideas about things going on in my community for me to think about. (collapsed from connectivity questions)

"Process Gratifications" questions

- I search for articles on a particular topic. 
- It's a good way to spend time.

- The site is high-tech in a way that appeals to me.

\section{Demographics Questions}

In this section, this final section, I am looking for some information about your background. Check the appropriate box to answer the question

- Name: (fill-in box); NOTE: You may decline to enter this information, but it is necessary if you would like to be entered in the drawing for the prize. The information entered in this box will only be used to notify you in the event you have won.

- E-mail address: (fill-in box); NOTE: You may decline to enter this information, but it is necessary if you would like to be entered in the drawing for the prize. The information entered in this box will only be used to notify you in the event you have won.

- Age: $18-25 ; 26-30 ; 31-35 ; 36-40 ; 41-45 ; 46-50 ; 51-55 ; 56-$ older

- Gender: Male; Female

- Education: Attended elementary school; Graduated from elementary; Attended high school; Graduated high school or trade school; Attended college; Graduated college; Postgraduate education

- Income: Less than $\$ 15,000 ; \$ 15,000-\$ 24,999 ; \$ 25,000-\$ 34,999 ; \$ 35,000$ $\$ 49,999 ; \$ 50,000-\$ 74,999 ; \$ 75,000-\$ 99,999 ; \$ 100,000-\$ 150,000 ;$ More than $\$ 150,000$; Don't know/Prefer not to state

- Marital status: Single; Married 


\section{REFERENCES}

AFP.com. (2005). Internet holds only future for newspapers, experts warn. Downloaded from http://news.yahoo.com/s/afp/spainmediaInternet on November 10, 2005

Almond, G. A., \& Verba, S. (1989). The civic culture: Political attitudes and democracy in five nations (3rd ed.). Newbury Park, CA: Sage Publications.

Althaus, S. L., \& Tewksbury, D. (2000). Patterns of Internet and traditional news media use in a networked community. Political Communication, 17, 21-45.

Ananny, M., \& Strohecker, C. (2002). Situated citizen photojournalism and a look at dilemmatic thinking, Association for the Advancement of Computing in Education's E-Learn Conference.Montreal, Canada.

Bakker, P. (2002). Free daily newspapers" business models and strategies. The International Journal on Media Management, 3(4), 180-187.

Bar-Ilan, J. (2004). An outsider's view on topic-oriented blogging: The Hebrew University of Jerusalem.

Beaudoin, C., \& Thorson, E. (2004). Social capital in rural and urban communities: Testing differences in media effects and models. Journalism and Mass Communication Quarterly, 81(2), 378-399.

Becker, L. B., \& Dunwoody, S. (1982). Media use, public affairs knowledge and voting in a local election. Journalism Quarterly, 59(2), 212-218.

Bentley, C., Littau, J., Hamman, B., Meyer, H., Welsh, B., \& Watson, B. (2005). The citizen journalism movement: MyMissourian as a case study, Association for Education in Journalism and Mass Communication. San Antonio, TX.

Bentley, C. H. (2004). Wanted: Your ideas, your prose, your photos. Retrieved Oct. 24, 2004, from http://groups.yahoo.com/group/freecycleColumbiaMO/

Blumler, J. G., \& Katz, E. (1974). The uses of mass communication. Newbury Park, CA: Sage.

Braiker, B. (2005, July 9, 2005). History's new first draft. Newsweek, (Web edition only).

Cannon, D. F. (2005). Church newspaper readership and faith community integration. Paper presented at the Association for Education in Journalism and Mass Communication, San Antonio, TX. 
Chyi, H. I., \& Lasorsa, D. (1999). Access, use and preferences for online newspapers. Newspaper Research Journal, 20(4), 3-13.

Chyi, H. I., \& Sylvie, G. (2001). The medium is global, the content is not: The role of geography in online newspaper markets. The Journal of Media Economics, 14(4), 231-248.

Deuze, M. (2003). The web and its journalisms: Considering the consequences of different types of news media online. New Media and Society, 5(2), 203-230.

Donohew, R. L., Nair, M., \& Finn, S. (1984). Automacity, arousal, and information exposure. In R. N. Bostrom (Ed.), Communication yearbook 8 (pp. 267-284). Beverly Hills, Calif.: Sage.

Dube, J. (2005). Northwest voice: Behind the scenes, Cyberjournalist.com (Vol. 2005, pp. Website): American Press Institute.

Dunleavy, D. (2005). Camera phones prevail: Citizen shutterbugs and the London bombings. The Digital Journalist, July 2005(93).

Eighmey, J., \& McCord, L. (1998). Adding value in the information age: Uses and gratifications of sites on the world wide web. Journal of Business Research, 41(3), 187-194.

Flanagin, A. J., \& Metzger, M. J. (2001). Internet use in the contemporary media environment. Human Communication Research, 27(1), 153-181.

Flink, S. E. (1997). Sentinel under siege: The triumphs and troubles of America's free press. Boulder, Colorado: Westview Press.

Fost, D. (2005, April 19, 2005). All the news that's fit to post: Newspapers figure out a future. San Francisco Chronicle, pp. D-1.

Frankel, G. (2005, July 13, 2005). Four Britons tied to London blasts. The Washington Post, p. A1.

Galiel, D. (2004). A lever long enough: Value driven enterprise in the networked information economy: Consortiuminfo.org.

Gillmor, D. (2004). We the media: Grassroots journalism by the people, for the people. Sebastopol, CA: O'Reilly Media.

Glaser, M. (2004). The new voices: Hyperlocal citizen media sites want you (to write)! Online Journalism Review: University of Southern California. 
Ha, L. (1995). Subscriber's behavior in electronic discussion groups: A comparison between academics and practitioners. Paper presented at the Conference on Telecommunications and Information Markets.

Ha, L., \& James, E. L. (1998). Interactivity reexamined: A baseline analysis of early business web sites. Journal of Broadcasting and Electronic Media, 42, 457-474.

Habermas, J. (Ed.). (1989). Offentilichkeit. Boston: Beacon Press.

Hall, P. A. (1999). Social capital in Britain. British Journal of Political Science, 29, 417461.

Hutchins, R. e. a. (1947). A free and responsible press: A general report on mass communication. Chicago, Illinois: University of Chicago Press.

Inglehart, R. (1997). Modernization and postmodernization: Cultural, economic, and political change in 43 countries. Princeton, New Jersey: Princeton University Press.

Katz, E. (1959). Mass communication research and the study of popular culture: An editorial note on a possible future for this journal. Studies in Public Communication, 2, 1-6.

Kaye, B. K., \& Johnson, T. J. (2002). Online and in the know: Uses and gratifications of the web for political information. Journal of Broadcasting and Electronic Media, 46(1), 54-71.

Klapper, J. T. (1963). Mass communication research: An old road resurveyed. Public Opinion Quarterly, 27, 515-527.

Knack, S., \& Keefer, P. (1997). Does social capital have an economic payoff? A crosscountry investigation. Quarterly Journal of Economics, 112, 1251-1288.

Krueger, C. C., \& Swatman, P. M. C. (2004). Developing e-business models in practice: The case of the regional online newspaper. International Journal of Information Technology and Management, 3(2-4).

Kubey, R., \& Csikszantmihalyi, M. (1990). Television and the quality of life: How viewing shapes everyday experience. Hillsdale, N.J.: Lawrence Erlbaum.

Leeson, P. T. (2005). Better together: Restoring the American community. American Journal of Economics and Sociology, 64(3). 
Lin, C. A. (2001). Audience attributes, media supplementation, and likely online service adoption. Mass Communication \& Society, 4(1), 19-38.

Maloney, R. (2005, November 10, 2005). As circulation falls, news seeks solutions. Buffalo Business First.

McCombs, M., \& Pointdexter, P. M. (1983). The duty to keep informed: News exposure and civic obligation. Journal of Communication, 33 (2 (Spring)), 88-96.

McCombs, M., \& Shaw, D. (1974). The agenda-setting function of mass media. Public Opinion Quarterly, 36, 176-185.

McQuail, D. (1994). Mass communication: An introduction (3rd ed.). London: Sage.

McQuail, D., Blumler, J. G., \& Brown, J. (1972). The television audience: A revised perspective. In D. McQuail (Ed.), Sociology of mass communication. Middlesex, England: Penguin.

Merrill, J. C., Gade, P. J., \& Blevens, F. R. (2001). Twilight of press freedom: The rise of people's journalism. Mahwah, New Jersey: Lawrence Erlbaum Associates.

Milton, J. (1986). Areopagitica and of education. Wheeling, Illinois: Harlan Davidson, Inc.

MSNBC. (2005). Citizen journalists report. From http://msnbc.msn.com/id/6639760/

Norris, P. (2002). The bridging and bonding role of online communities. The Harvard International Journal of Press/Politics, 7(3), 3-13.

Papacharissi, Z., \& Rubin, A. M. (2000). Predictors of Internet use. Journal of Broadcasting and Electronic Media, 44(2), 175-196.

Pateman, C. (1970). Participation and democratic theory. New York: Cambridge University Press.

Pointdexter, P. M., \& McCombs, M. (2001). Revisiting the civic duty to keep informed in the new media environment. Journalism Quarterly, 78(1), 113-126.

Putnam, R. (1993). Making democracy work: Civic traditions in modern Italy. Princeton, New Jersey: Princeton University Press.

Putnam, R. (1995). Bowling alone, revisited. The Responsive Community, 5(2), 18-33.

Putnam, R. (2001). Bowling alone. New York: Simon \& Schuster. 
Raeymaeckers, K. (2004). Newspaper editors in search of young readers: Content and layout strategies to win new readers. Journalism Studies, 5(2).

Rodzvilla, J. (Ed.). (2002). We've got blog: How weblogs are changing our culture. Cambridge, MA: Perseus Publishing.

Rosen, J., \& Merritt, D. (1994). Public journalism: Theory and practice. Dayton: Kettering Foundation.

Ruggiero, T. (2000). Uses and gratifications theory in the 21 st century. Mass Communication \& Society, 3(1), 3-37.

Schweiger, W \& Quiring, O. (2005). User-generated content on mass media web sites just a kind of interactivity or something completely different? Paper presented at the International Communication Association Conference, New York, NY.

Shah, D. V., Kwak, N., \& Hobert, R. L. (2001). "Connecting" and "disconnecting" with civic life: Patterns of Internet use and the production of social capital. Political Communication, 18, 141-162.

Singer, J. (1998). Online journalists: Foundations for research into their changing roles. Journal of Computer-Mediated Communication, 4(1).

Stafford, T. F., Stafford, M. R., \& Schkade, L. L. (2004). Determining uses and gratifications for the Internet. Decision Sciences, 35(2), 259-288.

Stanford, S., \& Riccomini, B. (1984). Linking TV program orientations and gratifications: An experimental approach. Journalism Quarterly, 61(1), 76-82.

Stempel III, G. S., Hargrove, T., \& Bernt, J. P. (2000). Relation of growth of use of the Internet to changes in media use from 1995 to 1999. Journalism and Mass Communication Quarterly, 77(1), 71-79.

Terdiman, D. (2004). Open arms for open-source news. Wired News, http://www.wired.com/news/culture/0,1284,64285,00.html?tw=wn_tophead_4, Downloaded February 28, 2005.

Uslaner, E. M. (2004). Trust, civic engagement, and the Internet. Political Communication, 21, 223-242.

Walker, A. K. (2005). Newspapers continue to decline in circulation. Baltimore Sun.

Whiteley, P. F. (2000). Economic growth and social capital. Political Studies, 48, 443466. 
Zillmann, D., \& Bryant, J. (1988). Mood management through communication choices. American Behavioral Scientist, 31, 327-340. 